\title{
PREDICTORS OF RECYCLING BEHAVIOUR INTENTIONS AMONG URBAN LITHUANIAN INHABITANTS
}

\author{
Indrẻ PIKTURNIENE் ${ }^{1}$, Greta BÄUMLE ${ }^{2}$ \\ ${ }^{1,2}$ ISM University of Management and Economics, Vilnius, Lithuania \\ Arkliu str. 18, Vilnius, Lithuania, LT 01305 , \\ E-mails: ${ }^{1}$ indre.pikturniene@ism.lt (corresponding author); ${ }^{2}$ greta.liachoviciute@gmail.com
}

Received 25 June 2014; accepted 03 August 2014

\begin{abstract}
In countries where no incentives for recycling prevail, individual recycling is grounded on citizens' consciousness and everyday efforts. Governmental actions can be effective only after understanding factors for recycling behaviour, and fostering them. Since the primary target group of recycling in Lithuania are urban inhabitants, it is important to determine what sub-segments of this group are the most likely to become innovators and early adopters in the field, and to identify what are the most important predictors of their recycling intentions. The aim of the study was to determine how values affect attitude elements towards recycling and what attitude elements and (or) recent recycling behaviour are the most important predictors of intentions to recycle; and to investigate what demographic groups among Lithuanian urban inhabitants are the most likely to be engaged in recycling. Survey using an instrument that allowed determining values, attitudes, subjective norm, perceived behavioural control, actual level of recycling, and link them to the intentions to recycle was performed among urban Lithuanian inhabitants. Results suggest two main strategies for social change managers: informing consumers to increase favourable attitudes towards recycling, and inducing recycling habit. The efforts should be primarily targeted towards educated people over 35, irrespective of gender.
\end{abstract}

Keywords: attitudes, values, theory of planned behaviour, recycling behaviour, recycling habits, Lithuanian urban inhabitants, social change.

JEL Classification: Q01, Q28, M30.

\section{Introduction}

Recycling ${ }^{1}$ is important for nature preservation; however, it is costly for state institutions. Therefore authorities in charge have a goal to shift part of the recycling burden on citizens by increasing their consciousness on the necessity of everyday recycling.

In Lithuania recycling level is lower than in other EU member states. Even though EU regulations concerning pollution prevention are common for all states, recycling practice

\footnotetext{
${ }^{1}$ Recycling in this paper will be understood as collection and separation of materials from waist for further processing and re-use which is implemented by individuals with support of authorities (supplemented definition of Davies et al. 2002).
} 
differs significantly. EU directives cover a number of recycling related areas, requiring states to reach particular levels of waste collection, reuse, and disposal of waste streams. Lithuania is among the states where citizens' recycling practice is still far below the desired level (Fischer, Davidsen 2010). There are no financial incentives to recycle in Lithuania, thus recycling activities heavily rely on peoples' motivation. Therefore, to get a deeper insight of insufficient recycling problems in Lithuania, the relationship of values, attitudes, habits and recycling practices of Lithuanian urban inhabitants is explored.

There is plenty of research on recycling predictors in developed states, early works starting from the seventies (De Young 1990; McCarty, Shrum 1993, 1994; Poortinga et al. 2004; Steininger, Voegtlin 1976). During the recent decade empirical evidence was supported by research from developing and young countries (Aung, Arias 2006; Culiberg, Bajde 2013; Ittiravivongs 2012; Ramayah, Rahbar 2013). Lithuania is still under-researched in this perspective. Reporting empirical evidence from countries in transition is important in management research, since knowledge about their markets and consumer behaviour will be critical for future global community (Schultz 2010).

In general, there are some specific characteristics of Lithuanian inhabitants recycling behaviour if compared to Western Europe, since household recycling is the most active in highly urbanised areas. However, the segment of urban inhabitants who are inclined to recycle is heterogeneous, whereas determining and targeting innovators and early adopters, followed by early majority is vital to induce social change in recycling (DuBois et al. 2013).

The study aims to determine how values affect attitude elements towards recycling, and what attitude elements and (or) recent recycling behaviour are the most important predictors of intentions to recycle among Lithuanian urban inhabitants.

\section{Factors of individual recycling behaviour}

Recycling of household waste is comparable to the public good, since the individual has to allocate his efforts and resources for the benefit to society, including those who refuse to contribute. Identifying factors of socially active and voluntary behaviour, and inducing the behaviour via them has drawn scholars and practitioners attention.

Many works in the area of pro-environmental behaviour research rely on models that include values, personal norms and attitudes as the major factors of social behaviour prediction (Davies et al. 2002; De Young 1990; Guering et al. 2001; McCarty, Shrum 1993, 1994; Stern et al. 1999; Oreg, Katz-Gero 2006; Poortinga et al. 2004). Originally, the models are based on Norm activation theory of Schwartz (1973), which postulates that major drivers of social behaviour are personal norms, and on the Theory of Planned Behaviour (Fishbein, Ajzen 1975), which explains elements related to attitudes and intentions to behave. The major factors of recycling behaviour are explored below.

\subsection{Influence of values on attitudes towards recycling, subjective norm, and perceived behavioural control}

Since social behaviour is a cognitive altruistic action, values are included as a starting point for understanding it. Values are desirable goals that serve as guiding principles 
in peoples' lives (Schwartz 1996), direct actions, and frame standards in evaluating behaviours and objects on individual or cultural level (Rokeach 1979). Consciousness in particular values and value congruent behaviour are characteristic for the innovators, early adopters and early majority in recycling (DuBois et al. 2013).

Most of the research does not consider values to be the direct predictors of recycling intentions or behaviour; rather, they work as antecedents of moderating variables, helping to shape attitude-related domains that are used for object assessment, leading to behavioural intentions and behaviours.

The explanation how particular values result in recycling related attitudes and behaviour can be based on arguments of Schwartz (1973) Norm Activation theory (herein after NAT) and Stern et al. (1999) Value-Belief-Norm theory. According to NAT, personal norms are activated and turn into attitudes when individual understands the behavioural consequences for the society (nature prevention). Individuals are more likely to activate particular norms under the social pressure, especially if external opinion is compatible with their own attitudes. If individuals attribute responsibility of performance, that is, recycling, to themselves, the likelihood of norm activation and particular action increases. Value-Belief-Norm theory argues that norm based actions are the result of personal values. If an individual feels that certain values could be violated by behaving in environmentally unfriendly way, and that prevention of violation is upon him/her, the activation of environmental norm, and consequently, behaviour, is more likely.

The research in values-recycling behaviour field proves the relationship of values and recycling related attitudes and behaviours. Although the major obstacle for categorisation and summary of surveys is differences in value typologies used as independent variables, several commonalities can be outlined.

Values of respect, self-fulfilment and achievement have positive relations with attitudes towards recycling (McCarty, Shrum 1994). Sense of responsibility for global problems and altruistic values highly correlate with recycling attitudes (Milfont et al. 2010). Moral recognition, moral judgement and altruism are interrelated domains that have positive impact on recycling importance recognition (Culiberg, Bajde 2013). The generalisation can be made that recycling related values are those that address the relationships and harmony with environment and better assessment of satisfaction with self. In particular, the following values from List of Values (herein after - LOV) (Kahle 1983) taxonomy are hypothesised to be significant positive predictors of attitudes towards recycling behaviour: sense of belonging, warm relationship with others, being well respected, self-fulfilment and self-respect (H1).

Values should affect how individuals react to other peoples' opinions, are how they are submitting to social pressure to recycle, since environmental behaviour is socially desirable. Unity and obedience, facets of conservative values according to Schwartz (1992) taxonomy, were reported to be differentiators among environmentalists and nonenvironmentalists (Gilg et al. 2005). Both domains refer to group influence, which is directly related to subjective norm, thus similar relationships should be observed using LOV taxonomy. Several values in LOV, namely, warm relationship with others, sense of belonging, and being well-respected, are directly related with relationships with others, what presumably can be enhanced by being engaged in positive behaviour. 
Quite surprisingly, fun and enjoyment was reported to have relationship with environmental behaviour (McCarty, Shrum 1994). It should be noted that the authors used the derivative construct of fun/enjoyment which included values of fun and enjoyment in life, warm relationship with others, and excitement, thus it is difficult to judge about the impact of one particular value. Still, the results of fun/enjoyment and recycling importance relationship might be explained by warm feelings that were evoked by being satisfied with responsible reasoned behaviour and peer-approval. Thus, H2 hypothesizes the above argued values to be positive predictors of subjective norm related to recycling. Perceived behavioural control (herein after - PBC) could be used as a moderating variable between values and recycling related behavioural intentions or behaviour (Oreg, Katz-Gerro 2006). In case of recycling behaviour, PBC is equated with conditions to recycle (infrastructure and other incentives or facilities offered by institutions). As norm activators (following NAT), values shape understanding in priorities of favourable behaviour vs. sacrifice and personal determination to overcome the impediments or difficulties to recycle. Again, values related to the relationship with others and self should be strong internal triggers to control routine effort demanding behaviour. H3 predicts the argued values to positive predictors of PBC that is related to recycling.

Table 1 sums up detailed hypotheses how selected values are expected to be the positive predictors of elements of TPB:

Table 1. Detailed hypotheses of values as significant positive predictors of attitude, subjective norms and perceived behavioural control in relation to recycling

\begin{tabular}{lccc}
\hline \multirow{2}{*}{ Value as predictor } & \multicolumn{3}{c}{ Dependent variable } \\
\cline { 2 - 4 } & Attitude & Subjective norm & Perceived behavioural control \\
\hline Sense of belonging & H1a & H2a & H3a \\
\hline Warm relationship with others & H1b & H2b & H3b \\
\hline Being well respected & H1c & H2c & H3c \\
\hline Fun and enjoyment & $\mathrm{x}$ & H2d & x \\
\hline Self-fulfilment & H1d & $\mathrm{x}$ & H3d \\
\hline Self-respect & H1e & x & H3e \\
\hline
\end{tabular}

\subsection{Influence of attitudes, subjective norm, $P B C$ and past recycling behaviour on intention to recycle}

Attitudes are learned biases to evaluate an object in positive or negative manner (Fishbein, Ajzen 1975). Since following this description the attitude is learned, it suggests that by changing certain attitude related factors or characteristics of the object under assessment individuals can be taught to shape attitudes in the desired way, thus opening the niche for social marketers in attitude formation.

Works report positive relationship between attitudes and intentions to behave in a socially conscious manner (Pelsmacker et al. 2005; Flamm 2009), including recycling (De Young 1990; Birgelen et al. 2009). 
The most acknowledged theory relating attitudes to behavioural intentions is the Theory of Planned Behaviour (herein after - TPB), where attitude is assumed to be the result of two beliefs: belief about the consequence that behaviour induces, and the importance of this consequence to an individual (Fishbein, Ajzen 1975).

According to TPB, behaviour depends not only on attitude, but also on subjective norm (perceived social opinion about the intended behaviour, which is weighted by the importance of that opinion). This postulate of TPB is compatible with Schwartz NAT, where social pressure is considered to be an activator of personal norms. Opinions and norms of reference groups (community) were reported to be important on actual recycling behaviour (Birgelen et al. 2009; Shackelford 2006). It is worth noting that counterarguments also exist. Pratarelli (2010) argues that social pressure to recycle hardly impacts in huge communities where individuals tend to remain anonymous and behaviour is private.

Perceived behavioural control (perceived factors that cause ease or difficulty of behaviour, which is weighted by the perceived ability to control the factor) is the third element that affects behavioural intentions according to TPB. This element is comparable to the "Ascription of responsibility" element according to NAT. Surveys reported possibility to recycle, sufficient space, perception of recycling as a (non)hassle to be important predictors of recycling intentions or actual recycling behaviour (De Young 1990; Oreg, Katz-Gerro 2006; Poortinga et al. 2004).

All three elements of TPB should lead to the intentions to perform certain behaviour. Kraus (1995) sums up 88 attitude-behaviour relationship studies and reports that in much more cases attitudes are sufficient predictors of behaviour than not.

It was demonstrated that recycling becoming a habit increases the probability of actual (future) recycling (Davies et al. 2002; Ittiravivongs 2012). Meneses and Palacio (2006) argue that since recycling is continuous and long term innovation, it becomes a low involvement construct. In low involvement conditions, when behaviour is not supported with cognitive reconsideration of decisions, it becomes routine both for recyclers and non-recyclers, however recyclers tend to continue the behaviour on the basis of habit. Also, current recycling followed by further intentions could be a signal that decision to recycle is well-determined rather than routine (Jansson et al. 2010).

Since the main intention was to test TPB model's predictability for recycling, the premise that intentions to recycle should be positively predicted by all elements of TPB was hold. Recycling behaviour should be the predictor of future intentions to recycle as well, leading to H4 (see Table 2 for detailed sub-hypotheses).

Table 2. Detailed hypotheses of attitude, subjective norm, perceived behavioural control and recent recycling behaviour as predictors of intentions to recycle

\begin{tabular}{cc}
\hline Value as predictor & Dependent variable: intention to recycle \\
\hline Attitudes & $\mathrm{H} 4 \mathrm{a}$ \\
\hline Subjective norm & $\mathrm{H} 4 \mathrm{~b}$ \\
\hline Perceived behavioural control & $\mathrm{H} 4 \mathrm{c}$ \\
\hline Recent recycling behaviour & $\mathrm{H} 4 \mathrm{~d}$ \\
\hline
\end{tabular}




\section{Methodology}

\subsection{Research aim}

Research aim was to determine how values affect attitude elements towards recycling, and what attitude elements and past recycling behaviour are the most important predictors of intentions to recycle among Lithuanian urban inhabitants. Additionally, the results will be broken by demographics to determine whether studied domains differ among genders, age groups and education levels.

\subsection{Measures}

The data was based on self-report survey. Researchers acknowledge that self-reporting is not the best tool of collecting data that relates internally derived domains and actual behaviour, especially in cases when measured domains include social desirability (Arnold, Feldman 1981). However, the data of self-reports is the easiest to obtain in a short time run, and sometimes the only one existing (for example, when attitudes are measured).

Intention to recycle was measured as an assessment of vision on future recycling behaviour within one year in 7 point Likert scale, where 1 represented non-recycling, and 7 represented 'recycling everything'. In a similar manner, intentions were studied by Park and Ha (2012).

Values of sense of belonging, fun and enjoyment, warm relationship with others, selffulfilment, being well respected, and self-respect were selected from LOV (Kahle 1983). Although there are a number of values taxonomies, LOV is widely adopted due to the applicability for consumer surveys and validity (Watkins, Gnoth 2005). Respondents were asked to assess how the listed values serve to them "as guiding principle in their life" in 7-point Likert scale.

Attitudes, social norms and PBC were measured following Ajzen (2005) methodology. A series of statements were provided for the respondents, asking to assess the following:

- For attitude: major consequences of the recycling behaviour (behavioural belief), and the importance of the outcome (for example, "Recycling helps to save natural resources", and "It is important for me to save natural resources").

- For subjective norm: pressure to recycle by parents, friends, colleagues, neighbours, government, experts (strength of normative belief), and the importance of their opinion (motivation to comply).

- For perceived behavioural control: factors affecting respondent's recycling such as time, space, knowledge, containers, decision making power (perceived power of control factors), and the importance of that factor (control belief).

Internal consistency of constructs was tested by Cronbach alpha, each of them demonstrating sufficient reliability (see Table 3).

For each variable, the weighted average was computed. Since each statement was multiplied by its importance, the variance of scale was from 1 to 49 .

Past recycling behaviour was measured by asking to assess recent recycling behaviour in 7 point Likert scale (1 meant non-recycling at all, 7 meant recycling everything). 
Table 3. Internal consistency of derivative measures

\begin{tabular}{llcc}
\hline Element of TPB & \multicolumn{1}{c}{ Construct } & No. of items & Cronbach alpha \\
\hline \multirow{2}{*}{ Attitudes } & $\begin{array}{l}\text { Behavioral beliefs that recycling will produce } \\
\text { particular result }\end{array}$ & 7 & 0.871 \\
\cline { 2 - 4 } & Importance of the recycling outcomes & 7 & 0.845 \\
\hline \multirow{2}{*}{\begin{tabular}{l} 
Subjective norm \\
\cline { 2 - 4 } $\begin{array}{l}\text { Perceived } \\
\text { behavioral } \\
\text { control }\end{array}$
\end{tabular}} & Strength of normative belief & 6 & 0.860 \\
\cline { 2 - 4 } & Control belief & 5 & 0.841 \\
\hline
\end{tabular}

Similarly, Diamantopoulos et al. (2003) measured recycling behaviour, except that the scale was broken by particular materials (glass, paper, etc.).

Data on gender, age, education and city of living was collected (categorical scale).

\subsection{Population, sampling and data collection}

The basic premise of the research was based on the peculiarity of Lithuania that urban and more educated inhabitants pursue ecology-related behaviour (Banyte et al. 2010). Most inhabitants of Lithuanian peripheral areas, especially low income and uneducated ones, are too concerned about their everyday poor conditions to start caring about recycling. Infrastructure for recycling is more favourable in urban areas. It was likely that collecting the data about peripheral inhabitants' opinions on recycling and actual behaviour would produce nil result, since it is rudimental in these areas. Thus, only citizens from cities were interviewed.

Convenience sampling via social networks was used in spring 2011. Respondents had to follow the link with uploaded questionnaire. The characteristics of target population (young, educated) assured that internet is appropriate and the most effective mean for collecting answers. After filtering responses for living place, country, and age over 18, 304 usable responses have remained.

\section{Results}

\subsection{Sample and variable distribution characteristics}

After cleaning the sample to assure that it represents population from three biggest Lithuanian cities (Vilnius, Kaunas and Klaipeda), the following profile of the sample was achieved: $69.4 \%$ of respondents were women, $30.6 \%$ were male; $74 \%$ had higher education; $46.9 \%$ of respondents were $19-24$ years old, $29.2 \%$ of respondents were 25-35 years old, $22.3 \%$ were $36-71$ years old.

To determine whether there are the differences between attitudes, subjective norms, $\mathrm{PBC}$, past recycling behaviour and intentions to recycle between genders, different age groups and education levels, t-test of independent samples and ANOVA were conducted. Although it could be expected that gender is differentiating factor for the environmental 
behaviour due to more caring nature of women and society oriented socialising patterns while educating girls (Diamantopoulos et al. 2003), it was not proven as differentiator in some of studies (Davies et al. 2002). Our results show that there are no differences in attitudes between genders in any of measured variables (see Table 4).

Both men and women assess their current recycling level below the average, but have much higher intentions to recycle. Attitudes towards recycling per se are higher than scale average.

People having higher education have stronger intentions to recycle, report higher current recycling level, and have stronger expressed attitudes towards recycling (see Table 5).

Table 4. Differences in recent recycling level, intentions to recycle, attitudes towards recycling, subjective norm, and PBC among male and female

\begin{tabular}{|c|c|c|c|c|c|c|}
\hline & Gender & $\mathrm{N}$ & Mean & Standard deviation & $\mathrm{t}$ & Significance (2-tailed) \\
\hline \multirow{2}{*}{ Intentions to recycle } & Male & 91 & 4.04 & 1.632 & -1.311 & 0.191 \\
\hline & Female & 210 & 4.33 & 1.769 & -1.354 & 0.177 \\
\hline \multirow{2}{*}{$\begin{array}{l}\text { Assessment of recent } \\
\text { recycling level }\end{array}$} & Male & 91 & 2.93 & 1.672 & 0.391 & 0.696 \\
\hline & Female & 210 & 2.85 & 1.800 & 0.402 & 0.688 \\
\hline \multirow{2}{*}{$\begin{array}{l}\text { Attitudes towards } \\
\text { recycling }\end{array}$} & Male & 93 & 31.66 & 12.057 & -1.542 & 0.124 \\
\hline & Female & 211 & 33.61 & 9.241 & -1.393 & 0.166 \\
\hline \multirow{2}{*}{ Subjective norm } & Male & 93 & 16.40 & 10.215 & 0.513 & 0.608 \\
\hline & Female & 209 & 15.77 & 9.552 & 0.500 & 0.618 \\
\hline \multirow{2}{*}{$\begin{array}{l}\text { Perceived behavioural } \\
\text { control }\end{array}$} & Male & 92 & 20.02 & 10.227 & 0.713 & 0.476 \\
\hline & Female & 210 & 19.15 & 9.537 & 0.694 & 0.489 \\
\hline
\end{tabular}

Table 5. Differences in intentions to recycle, recent recycling behaviour, attitude towards recycling, subject norm and $\mathrm{PBC}$ between people holding higher education and not holding higher education (HE)

\begin{tabular}{|c|c|c|c|c|c|c|}
\hline & Education & $\mathrm{N}$ & Mean & Standard deviation & $\mathrm{t}$ & Significance (2-tailed) \\
\hline \multirow{2}{*}{ Intentions to recycle } & Hold HE & 224 & 4.37 & 1.697 & 2.708 & 0.007 \\
\hline & Without HE & 51 & 3.65 & 1.776 & 2.631 & 0.010 \\
\hline \multirow{2}{*}{$\begin{array}{l}\text { Assessment of recent } \\
\text { recycling level }\end{array}$} & Hold HE & 224 & 2.99 & 1.783 & 2.406 & 0.017 \\
\hline & Without HE & 51 & 2.33 & 1.596 & 2.580 & 0.012 \\
\hline \multirow{2}{*}{$\begin{array}{l}\text { Attitudes towards } \\
\text { recycling }\end{array}$} & Hold HE & 227 & 33.53 & 9.646 & 2.064 & 0.040 \\
\hline & Without HE & 51 & 30.32 & 11.753 & 1.823 & 0.073 \\
\hline \multirow{2}{*}{ Subjective norm } & Hold HE & 225 & 15.79 & 9.076 & -0.116 & 0.908 \\
\hline & Without HE & 51 & 15.96 & 12.537 & -0.095 & 0.925 \\
\hline \multirow{2}{*}{$\begin{array}{l}\text { Perceived } \\
\text { behavioural control }\end{array}$} & Hold HE & 225 & 19.73 & 9.767 & 1.752 & 0.081 \\
\hline & Without HE & 51 & 17.07 & 9.977 & 1.728 & 0.088 \\
\hline
\end{tabular}


Even if university education is not related to environmental issues directly, knowledge of educated people allows them to relate abundant information about the necessity to recycle with positive outcomes for the entire society.

Subjective norm and PBC are perceived equally among educational groups. Both domains are related to the external pressure (social or infrastructural/circumstantial) to be (not)involved in the recycling behaviour, which apparently is the same for all citizens. Judging upon the means, the social pressure is quite low.

Assessment of PBC is also low for both genders and educational groups. Since the statements were formulated in the manner which required to assess the sufficiency of resources for recycling and their importance, low assessment demonstrates insufficiency of time, space, special containers, knowledge and decision making for the recycling. Stating it otherwise, respondents perceive that they have little control over recycling, and external or internal circumstances hinder them.

Respondents were divided into three groups according to age: 19-24, 25-35, and 36-71. Table 6 demonstrates that all elements under investigation except perceived behavioural control are significantly different for different age groups.

Statistically significant differences in analysed domains appear only when younger and older groups of the sample are contrasted (19-24 vs. 36-71). The group of 25-35 stands in the middle and does not deviate from other two groups significantly. People over 35 tend to have more favourable attitudes towards recycling, are suppressed stronger by the norms; they were more engaged in recycling in the past, and tend to be more engaged in the future, if compared to the youngest group.

Thus, education and age groups are the most important demographics to segregate recyclers from non-recyclers. Educated people older than 35 years are more likely to be involved in these activities, however, obstacles for recycling are perceived equally.

\subsection{Relationship of values with elements of TPB}

To assess what values are the predictors of attitudes, subjective norms, and recycling behaviour, hierarchical regression was performed for each dependent variable.

As indicated in Table 7, attitudes towards recycling can be predicted by sense of belonging and warm relationship with others. Subjective norm can be predicted by fun and enjoyment only. PBC can be predicted by being well respected. All the models are significant; however, all of them have $\mathrm{R}^{2}$ lower than 0.25 , which is the desired margin for explanatory models.

Only a small fraction of hypotheses were confirmed: H1a, H1b, H2d, H3b. Sense of belonging, warm relationship with others, fun and enjoyment allow judging upon individual attitudes, subjective norms, and perceived behavioural control related to recycling. However, low explanatory power of models suggests that identified values are insufficient predictors of dependent variables in question. The results are compatible with general characteristics of values - they hardly serve as predictors of everyday 
Table 6. Differences in intentions to recycle, recent recycling behaviour, attitude towards recycling, subjective norm and $\mathrm{PBC}$ between different age groups

\begin{tabular}{|c|c|c|c|c|c|c|c|c|c|}
\hline $\begin{array}{l}\text { Dependent variable } \\
\text { and sum of squares }\end{array}$ & $\begin{array}{l}\text { Age } \\
\text { group }\end{array}$ & $\mathrm{N}$ & Mean & $\begin{array}{l}\text { St. } \\
\text { dev. }\end{array}$ & $\begin{array}{l}\text { Group for } \\
\text { comparison } \\
\text { (Bonferoni) }\end{array}$ & $\begin{array}{l}\text { Mean } \\
\text { diff. }\end{array}$ & Sig. & $\mathrm{F}$ & Sig. \\
\hline \multirow{6}{*}{$\begin{array}{l}\text { Intentions to recycle } \\
\text { Between groups } \\
(2)=26.57, \\
\text { Within groups } \\
(294)=865.50 \text {, total } \\
(296)=892.06\end{array}$} & \multirow[t]{2}{*}{$19-24$} & \multirow[t]{2}{*}{143} & \multirow[t]{2}{*}{4.05} & \multirow[t]{2}{*}{1.680} & $25-35$ & -0.11 & 1.000 & \multirow{6}{*}{4.512} & \multirow{6}{*}{0.012} \\
\hline & & & & & $36-71$ & -0.75 & 0.010 & & \\
\hline & \multirow[t]{2}{*}{$25-35$} & \multirow[t]{2}{*}{89} & \multirow[t]{2}{*}{4.16} & \multirow[t]{2}{*}{1.846} & $19-24$ & 0.11 & 1.000 & & \\
\hline & & & & & $36-71$ & -0.63 & 0.072 & & \\
\hline & \multirow[t]{2}{*}{$36-71$} & \multirow[t]{2}{*}{68} & \multirow[t]{2}{*}{4.79} & \multirow[t]{2}{*}{1.617} & $19-24$ & 0.75 & 0.010 & & \\
\hline & & & & & $25-35$ & 0.63 & 0.072 & & \\
\hline \multirow{6}{*}{$\begin{array}{l}\text { Assessment of recent } \\
\text { recycling level } \\
\text { Between groups } \\
(2)=30.94 \text {, } \\
\text { Within groups } \\
(294)=892.70, \\
\text { total }(296)=923.64\end{array}$} & \multirow[t]{2}{*}{$19-24$} & \multirow[t]{2}{*}{143} & \multirow[t]{2}{*}{2.62} & \multirow[t]{2}{*}{1.723} & $25-35$ & -0.24 & 0.953 & \multirow{6}{*}{5.094} & \multirow{6}{*}{$\mathbf{0 . 0 0 7}$} \\
\hline & & & & & $36-71$ & -0.82 & 0.005 & & \\
\hline & \multirow[t]{2}{*}{$25-35$} & \multirow[t]{2}{*}{89} & \multirow[t]{2}{*}{2.86} & \multirow[t]{2}{*}{1.757} & $19-24$ & 0.24 & 0.953 & & \\
\hline & & & & & $36-71$ & -0.58 & 0.123 & & \\
\hline & \multirow[t]{2}{*}{$36-71$} & \multirow[t]{2}{*}{68} & \multirow[t]{2}{*}{3.44} & 1.765 & $19-24$ & 0.82 & 0.005 & & \\
\hline & & & & & $25-35$ & 0.58 & 0.123 & & \\
\hline Attitudes towards & $19-24$ & 143 & 31.43 & 10.278 & $25-35$ & -1.79 & 0.558 & & \\
\hline $\begin{array}{l}\text { Between groups } \\
\text { Becying }\end{array}$ & & & & & $36-71$ & $-\mathbf{5 . 0 2}$ & 0.002 & & \\
\hline$(2)=1161.44$ & $25-35$ & 89 & 33.22 & 10.098 & $19-24$ & 1.79 & 0.558 & & 00 \\
\hline $\begin{array}{l}\text { Within groups } \\
(295)=29814.19\end{array}$ & & & & & $36-71$ & -3.22 & 0.140 & & \\
\hline total $(297)=30975.63$ & $36-71$ & 68 & 36.45 & 9.360 & $19-24$ & 5.02 & 0.002 & & \\
\hline & & & & & $25-35$ & 3.22 & 0.140 & & \\
\hline Subjective norm & $19-24$ & 143 & 14.74 & 9.133 & $25-35$ & -0.82 & 1.000 & & \\
\hline $\begin{array}{l}\text { Between groups } \\
(2)=800.50\end{array}$ & & & & & $36-71$ & -4.17 & 0.012 & & \\
\hline Within groups & $25-35$ & 89 & 15.56 & 9.421 & $19-24$ & 0.82 & 1.000 & 4320 & 0014 \\
\hline $\begin{array}{l}(295)=27273.70, \\
\text { total }(297)=280742\end{array}$ & & & & & $36-71$ & -3.35 & 0.098 & 1.021 & \\
\hline & $36-71$ & 68 & 18.91 & 10.826 & $19-24$ & 4.17 & 0.012 & & \\
\hline & & & & & $25-35$ & 3.35 & 0.098 & & \\
\hline Perceived behavioural & $19-24$ & 143 & 18.75 & 9.423 & $25-35$ & -1.06 & 1.000 & & \\
\hline Between groups & & & & & $36-71$ & -1.28 & 1.000 & & \\
\hline$(2)=101.26$ & $25-35$ & 89 & 19.81 & 9.908 & $19-24$ & 1.06 & 1.000 & 0530 & 0580 \\
\hline $\begin{array}{l}\text { Within groups } \\
(295)=28166.31\end{array}$ & & & & & $36-71$ & -0.22 & 1.000 & & \\
\hline total $(297)=28267.57$ & $36-71$ & 68 & 20.03 & 10.309 & $19-24$ & 1.28 & 1.000 & & \\
\hline & & & & & $25-35$ & 0.22 & 1.000 & & \\
\hline
\end{tabular}


behaviour, but rather give guidelines for the criteria in selecting and assessing behaviour (Beatty et al. 1985). Also, individuals hold value systems rather than single wellexpressed values (Schwartz 1992). It can be predicted that more latent variables intervene between values and attitudes, subjective norms, and $\mathrm{PBC}$ in the context of recycling.

Table 7. Values as attitude, subjective norm and PBC predictors: summary of multiple regression model coefficients

\begin{tabular}{|c|c|c|c|c|c|c|c|}
\hline $\begin{array}{l}\text { Dependent } \\
\text { variable } \\
\text { and model } \\
\text { coefficients }\end{array}$ & $\begin{array}{l}\text { Potential } \\
\text { predictor }\end{array}$ & $\begin{array}{l}\text { Unstand. } \\
\text { coefficient } \\
\text { B }\end{array}$ & beta & $\mathrm{t}$ & Sig. & $\begin{array}{l}\text { H. } \\
\text { No. }\end{array}$ & Accepted/rejected \\
\hline \multirow{6}{*}{$\begin{array}{l}\text { Attitude } \\
\mathrm{N}=297 \\
\mathrm{R}^{2}=0.119 \\
F=7.833 \\
p=0.000\end{array}$} & \multicolumn{7}{|c|}{ Constant $=16.954$} \\
\hline & $\begin{array}{l}\text { Sense of } \\
\text { belonging }\end{array}$ & 1.374 & 0.195 & 2.684 & 0.008 & H1a & Accepted \\
\hline & $\begin{array}{l}\text { Warm } \\
\text { relationship } \\
\text { with others }\end{array}$ & 1.575 & 0.188 & 2.447 & 0.015 & H1b & Accepted \\
\hline & $\begin{array}{l}\text { Being well } \\
\text { respected }\end{array}$ & 0.251 & 0.031 & 0.480 & 0.632 & $\mathrm{H} 1 \mathrm{c}$ & Rejected \\
\hline & Self-fulfilment & -0.507 & -0.051 & -0.795 & 0.096 & H1d & Rejected \\
\hline & Self-respect & 0.060 & 0.006 & 0.103 & 0.918 & H1e & Rejected \\
\hline \multirow{5}{*}{ 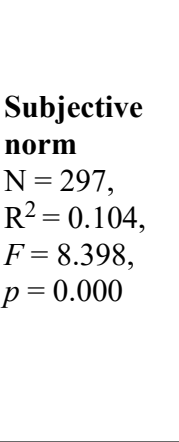 } & \multicolumn{7}{|c|}{ constant $=-1.736$} \\
\hline & $\begin{array}{l}\text { Being well } \\
\text { respected }\end{array}$ & 0.529 & 0.068 & 1.134 & 0.258 & $\mathrm{H} 2 \mathrm{c}$ & Rejected \\
\hline & $\begin{array}{l}\text { Sense of } \\
\text { belonging }\end{array}$ & 0.955 & 0.139 & 1.899 & 0.059 & $\mathrm{H} 2 \mathrm{a}$ & Rejected \\
\hline & $\begin{array}{l}\text { Warm } \\
\text { relationship } \\
\text { with others }\end{array}$ & 0.929 & 0.114 & 1.507 & 0.133 & $\mathrm{H} 2 \mathrm{~b}$ & Rejected \\
\hline & $\begin{array}{l}\text { Fun and } \\
\text { enjoyment }\end{array}$ & 0.801 & 0.124 & 2.105 & 0.036 & H2d & Accepted \\
\hline \multirow{6}{*}{$\begin{array}{l}\text { Perceived } \\
\text { behavioural } \\
\text { control } \\
\mathrm{N}=296 \\
\mathrm{R}^{2}=0.045 \\
\mathrm{~F}=2.733 \\
p=0.020\end{array}$} & \multicolumn{7}{|c|}{ constant $=8.508$} \\
\hline & $\begin{array}{l}\text { Sense of } \\
\text { belonging }\end{array}$ & 0.004 & 0.001 & 0.008 & 0.093 & $\mathrm{H} 3 \mathrm{a}$ & Rejected \\
\hline & $\begin{array}{l}\text { Warm } \\
\text { relationship } \\
\text { with others }\end{array}$ & 1.666 & 0.204 & 2.580 & 0.010 & H3b & Accepted \\
\hline & $\begin{array}{l}\text { Being well } \\
\text { respected }\end{array}$ & -0.735 & -0.095 & -1.410 & 0.160 & $\mathrm{H} 3 \mathrm{c}$ & Rejected \\
\hline & Self-fulfilment & 0.348 & 0.036 & 0.544 & 0.587 & H3d & Rejected \\
\hline & Self-respect & 0.464 & 0.049 & 0.788 & 0.431 & $\mathrm{H} 3 \mathrm{e}$ & Rejected \\
\hline
\end{tabular}




\subsection{Relationship between attitudes, subjective norm, PBC, past recycling behaviour and intentions to recycle}

To reveal what domains would serve as predictors of future intentions to recycle hierarchical regression was used with elements of TPB as independent variables, and intention to recycle as dependent variable. It showed that attitudes towards behaviour and assessment of recent recycling level very well explain intentions to recycle $\left(R^{2}=0.593\right)$. The suggested relationships in the model were as demonstrated in Table 8 .

Table 8. Attitudes towards recycling, subjective norm, PBC, and assessment of recent recycling level as predictors of intentions to recycle: summary of multiple regression model coefficients

\begin{tabular}{|c|c|c|c|c|c|c|c|}
\hline $\begin{array}{l}\text { Dependent } \\
\text { variable } \\
\text { and model } \\
\text { coefficients }\end{array}$ & $\begin{array}{l}\text { Potential } \\
\text { predictors, } \\
\text { identified by } \\
\text { regression }\end{array}$ & $\begin{array}{l}\text { Unstand. } \\
\text { coefficient } \\
\text { B }\end{array}$ & beta & $\mathrm{t}$ & Sig. & $\begin{array}{l}\text { H. } \\
\text { No. }\end{array}$ & Accepted/Rejected \\
\hline \multirow{5}{*}{$\begin{array}{l}\text { Intention to } \\
\text { recycle } \\
\mathrm{N}=298, \\
\mathrm{R}^{2}=0.593, \\
F=106.927, \\
p=0.000\end{array}$} & \multicolumn{7}{|c|}{ Constant $=1.010$} \\
\hline & $\begin{array}{l}\text { Attitude } \\
\text { towards } \\
\text { recycling }\end{array}$ & 0.034 & 0.195 & 4.641 & 0.000 & H4a & Accepted \\
\hline & $\begin{array}{l}\text { Subjective } \\
\text { norm }\end{array}$ & 0.000 & -0.003 & -0.056 & 0.955 & $\mathrm{H} 4 \mathrm{~b}$ & Rejected \\
\hline & $\begin{array}{l}\text { Perceived } \\
\text { behavioural } \\
\text { control }\end{array}$ & 0.014 & 0.078 & 1.549 & 0.122 & $\mathrm{H} 4 \mathrm{c}$ & Rejected \\
\hline & $\begin{array}{l}\text { Assessment } \\
\text { of recent } \\
\text { recycling level }\end{array}$ & 0.648 & 0.657 & 15.100 & 0.000 & H5 & Accepted \\
\hline
\end{tabular}

The recent recycling level is the major predictor of future recycling behaviour. Attitudes towards recycling are also important and can be tracked and used as predictors of intentions to recycle. $\mathrm{H} 4 \mathrm{a}$ and $\mathrm{H} 4 \mathrm{~d}$ are confirmed.

\section{Conclusions}

The paper contributes to the understanding what factors influence intentions to recycle in both theoretical and practical way. From the theoretical perspective, it tests the applicability of TPB on intentions to recycle. If compared to previous models that used values and TPB elements as recycling predictors, current paper is supplemented with past recycling behaviour as a variable, which proved to be a significant predictor of recycling. From the practical perspective, it identifies what factors are important predictors of recycling intentions in Lithuania, and explores recycling behaviour related domains among different demographic groups, identifying the segments who are the most recycling-sensitive.

The most important values that are related to attitudes, subjective norms and PBC are external, or related to other people, that is, sense of belonging and warm relations with 
others. This proves McCarty and Shrum (1993) findings that external values are important for positive recycling attitudes. Surprisingly, value of fun and enjoyment was statistically significant predictor of subjective norm. However, tested models with values as predictor of elements of TPB have too little explanatory power, therefore the results should be taken and interpreted with caution.

For the social marketer aiming to enhance recycling, the main target group should be people who already recycle and tend to recycle more: older than 35 years and holding higher education degree, irrespective of gender. These segments form innovator and early majority groups of individual recycling in Lithuania, and later they will serve as example for the follower groups. However, it should be noted that only personal example of others will be insufficient to catalyse recycling behaviour among follower groups, since subjective norm for this kind of behaviour was reported to be low in general, also it does not serve as the predictor of current or intended recycling level. Sequentially, addressing opinion of peers as a pressure to recycle will not serve as sufficient tool in marketing communication. The finding supports Pratarelli (2010) arguments that recycling, as a private action, does not become evident in huge communities and thus it is not affected by social norms.

Lower than scale average value of PBC should draw authorities' attention: people claim that their resources for recycling are insufficient (although the factor of perceiving low control over the circumstances did not serve as significant predictor in the model).

Results demonstrate that recycling becoming a habit has strong relationship with future recycling. Our methodology did not allow differentiating whether the relationship of current and intended recycling is due to high determination to adopt and pursue the behaviour or due to routine low involvement habit. The major problem here is a closed-loop situation, when in order to be a future recycler individual has to be current recycler, and inducing current recycling requires a number of triggers. However, the results should be long term.

Application of the findings should be introduced only having regard to the limitations, namely, self-response of socially desirable behaviour and sampling. Judging upon low reported current recycling level, self-response bias did not push the results towards higher assessments substantially. The sample was drawn on the convenience basis, a priori targeting population of urban Lithuanians who are more likely to recycle. It is very likely that inhabitants of smaller cities or villages would have less favourable attitudes towards recycling, lower recycling levels and intentions to recycle. However, recycling actions are more visible in smaller settlements, and pressure from peers might be higher, thus affecting the subjective norm towards recycling as a factor.

Even though the suggested initiatives are costly, low level of recycling in Lithuania might result in high financial penalties for every day of EU requirements' satisfaction delay. Having these potential costs in mind, costs of better recycling infrastructure and social marketing should be assessed in a different light.

Identifying more latent variables besides values, attitudes, social norms and PBC that would explain recycling actions and intentions, also relating them into one model, would 
be recommendatory for further research. Also, further research should aim towards understanding recycling misbehaviour of those groups who are currently characterised as non-recyclers. The explanation of the relationship among recyclers and non-recyclers groups (who and how becomes an opinion leader, what triggers non-recyclers to follow recyclers, what inter-group communication should be induced and how) would contribute to practical and scholarly value.

\section{References}

Ajzen, I. 2005. Attitudes, personality and behaviour. $2^{\text {nd }}$ ed. Maidenhead: Open University press. Arnold, H. J.; Feldman, D. C. 1981. Social desirability response bias in self-report choice situations, Academy of Management Journal 24(2): 377-385. http://dx.doi.org/10.2307/255848

Aung, M.; Arias, M. L. 2006. Examining waste management in San Pablo del Lago, Ecuador: a behavioral framework, Management of Environmental Quality: An International Journal 17(6): 740-752. http://dx.doi.org/10.1108/14777830610702557

Banytė, J.; Brazionienè, L.; Gadeikiené, A. 2010. Investigation of green consumer profile: a case of Lithuanian market of eco friendly food products, Economics \& Management 15: 374-383.

Beatty, S. E.; Kahle, L. R.; Homer, P.; Misra, S. 1985. Alternative measurement approaches to consumer values: the list of values and the Rokeach value survey, Psychology \& Marketing 2(3): 181-200. http://dx.doi.org/10.1002/mar.4220020305

Birgelen, M.; Semeijin, J.; Keicher, M. 2009. Packaging and proenvironmental consumption behaviour: investigating purchase and disposal decisions for beverages, Environment and Behaviour 41(1): 125-146. http://dx.doi.org/10.1177/0013916507311140

Culiberg, B.; Bajde, D. 2013. Consumer recycling: an ethical decision making process, Journal of Consumer Behaviour 12(6): 449-459. http://dx.doi.org/10.1002/cb.1446

Davies, J.; Foxall, G.R.; Pallister, J. 2002. Beyond the intention-behaviour mythology: an integrated model of recycling, Marketing Theory 2(1): 29-113.

http://dx.doi.org/10.1177/1470593102002001645

De Young, R. 1990. Recycling as appropriate behaviour: a review of survey data from selected recycling education programs in Michigan, Resources, Conservation and Recycling 3: 253-266. http://dx.doi.org/10.1016/0921-3449(90)90022-V

Diamantopoulos, A.; Schlegelmilch, B. B.; Sinkovics, R. R.; Bohlen, G. M. 2003. Can sociodemographics still play a role in profiling green consumers? A review of the evidence and an empirical investigation, Journal of Business Research 56(6): 465-480.

http://dx.doi.org/10.1016/S0148-2963(01)00241-7

DuBois, C. L. A.; Astakhova, M. N.; DuBois, D. A. 2013. Motivating behaviour change to support organizational environmental sustainability goals, Chapter 10 in A. H. Hufmann, S. R. Klein (Eds.) Green organizations: driving change with I-O psychology. New York, NY: Routledge.

Fischer, R.; Davidsen, C. 2010. Europe as a recycling society. The European recycling map, working paper [online], [cited 23 June 2014]. ETC/SCP. Available from Internet: http://scp.eionet.europa.eu/publications/WP2010_5_The\%20European\%20Recycling\%20Map/wp/WP2010_5 Fishbein, M.; Ajzen, I. 1975. Belief, attitude, intention, and behaviour: an introduction to theory and research. Reading, MA: Addison-Wesley.

Flamm, B. 2009. The impacts of environmental knowledge and attitudes on vehicle ownership and use, Transportation Research Part D: Transport and Environment 14(4): 272-279.

http://dx.doi.org/10.1016/j.trd.2009.02.003 
Gilg, A.; Barr, S.; Ford, N. 2005. Green consumption or sustainable lifestyles? Identifying the sustainable consumer, Futures 37(6): 481-504. http://dx.doi.org/10.1016/j.trd.2009.02.003

Guerin, D.; Crete, J.; Mercier, J., 2001. A multilevel analysis of the determinants of recycling behavior in the European countries, Social Science Research 30: 195-218.

http://dx.doi.org/10.1006/ssre.2000.0694

Ittiravivongs, A. 2012. Recycling as habitual behavior: the impact of habit on household waste recycling behavior in Thailand, Asian Social Science 8(6): 74-81.

http://dx.doi.org/10.5539/ass.v8n6p74

Jansson, J.; Marell, A.; Nordlund, A. 2010. Green consumer behavior: determinants of curtailment and eco-innovation adoption, Journal of Consumer Marketing 27(4): 358-370.

http://dx.doi.org/10.1108/07363761011052396

Kahle, L. R. 1983. Social values and social change: adaptation to life in America. New York: Praeger.

Kraus, S. J. 1995. Attitudes and the prediction of behavior: a meta-analysis of the empirical literature, Personality and Social Psychology Bulletin 21(1): 58-75.

http://dx.doi.org/10.1177/0146167295211007

McCarty, J. A.; Shrum, L. J. 1993. A structural equation analysis of the relationships of personal values, attitudes and beliefs about recycling, and the recycling of solid waste products, in L. McAlisler, M. L. Rothschild (Eds.). Advances in consumer research 20: 641-646.

McCarty, J. A.; Shrum, L. J. 1994. The recycling of solid wastes: personal values, value orientations, and attitudes about recycling as antecedents of recycling behaviour, Journal of Business Research 30: 53-62. http://dx.doi.org/10.1016/0148-2963(94)90068-X

Meneses, G. D.; Palacio, A. B. 2006. Different kinds of consumer response to the reward recycling technique: similarities at the desired routine level, Asia Pacific Journal of Marketing and Logistics 18(1): 43-60

Milfont, T. L.; Sibley, C. G.; Duckitt, J. 2010. Testing the moderating role of the components of Norm Activation on the relationship between values, Journal of Cross-Cultural Psychology 41(1): 124-131. http://dx.doi.org/10.1177/0022022109350506

Oreg, S.; Katz-Gerro, T. 2006. Predicting proenvironmental behaviour cross-nationally: values, the theory of planned behaviour, and Value-Belief-Norm theory, Environment and Behaviour 38(4): 462-483. http://dx.doi.org/10.1177/0013916505286012

Park, J.; Ha, S. 2012. Understanding pro-environmental behavior: a comparison of sustainable consumers and apathetic consumers, International Journal of Retail \& Distribution Management 40(5): 388-403. http://dx.doi.org/10.1108/09590551211222367

Pelsmacker, P. D.; Janssens, W.; Mielants, C. 2005. Consumer values and fair-trade beliefs, attitudes and buying behavior, International Review on Public and Nonprofit Marketing 2(2): 50-69.

Poortinga, W.; Steg, L.; Vlek, C. 2004. Values, environmental concern, and environmental behaviour. A study into household energy use, Environment and Behaviour 36(1): 70-93.

http://dx.doi.org/10.1177/0013916503251466

Pratarelli, M. E. 2010. Social pressure and recycling: a brief review, commentary and extensions, Surveys and Perspectives Integrating Environment and Society 3(1) [online], [cited 23 June 2014]. Available from Internet: http://sapiens.revues.org/905

Ramayah, T.; Rahbar, E. 2013. Greening the environment through recycling: an empirical study, Management of Environmental Quality: An International Journal 24(6): 782-801.

http://dx.doi.org/10.1108/MEQ-07-2012-0054

Rokeach, M. 1979. From individual to institutional values: with special reference to the values of science, in M. Rokeach (Ed.). Understanding human values. New York: Free Press, 47-70. 
Schultz, D. E. 2010. Communications between organizations and their markets in emerging economies: a research agenda, Organizations and Markets in Emerging Economies 1(1): 51-67.

Schwartz, S. H. 1992. Universals in the content and structure of values: theoretical advances and empirical test in 20 countries, Advances in Experimental Social Psychology 10: 221-279. http://dx.doi.org/10.1016/S0065-2601(08)60358-5

Schwartz, S. H. 1973. Normative explanations of helping behavior: a critique, proposal, and empirical test, Journal of Experimental Social Psychology 9: 349-364.

http://dx.doi.org/10.1016/0022-1031(73)90071-1

Schwartz, S. H. 1996. Value priorities and behaviour: applying of theory of integrated value systems, in C. Seligman, J. M. Olson, M. P. Zanna (Eds.). The Psychology of Values: The Ontario Symposium 8: 1-24. Hillsdale, NJ: Erlbaum.

Shackelford, T. K. 2006. Recycling, evolution and the structure of human personality, Personality and Individual Differences 41: 1551-1556.

http://dx.doi.org/10.1016/j.paid.2006.07.020

Steininger, M.; Voegtlin, K. 1976. Attitudinal bases of recycling, Journal of Social Psychology 100(1): 155-156. http://dx.doi.org/10.1080/00224545.1976.9711922

Stern, P. C.; Dietz, T.; Abel, T.; Guagnano, G. A.; Kalof, L. 1999. A Value-Belief-Norm theory of support for social movements: the case of environmentalism, Human Ecology Review 6: 81-97.

Watkins, L.; Gnoth, J. 2005. Methodological issues in using Kahle's list of values scale for Japanese tourism behaviour, Journal of Vacation Marketing 11(3): 225-233.

http://dx.doi.org/10.1177/1356766705055708

Indrė PIKTURNIENE் (Assoc. Prof. Dr) is a lecturer of Marketing and Consumer behaviour at ISM University of Management and Economics. She is a graduate of Vilnius University (Lithuania) and Lund University (Sweden). Her doctoral degree was granted at Kaunas University of Technology (Lithuania). Her major research interests include variety of consumer behaviour aspects and marketing implications of them.

Greta BÄUMLE is MSc of International Marketing and Management at ISM University of Management and Economics. Her research interests include attitudes towards behaviour. She was granted Master degree in 2011 and now is involved in international business practice as a marketing specialist. 